\title{
Kartun sebagai Media Komunikasi Visual Materi Ajar di Dunia Pendidikan
}

\author{
https://doi.org/10.25008/caraka.v2i2.60 \\ Sujendro Hery Nugroho, Poppy Ruliana \\ Sekolah Tinggi IImu Komunikasi (STIKOM) InterStudi - Jakarta
}

\begin{abstract}
Learning media is an inseparable part of the world of education. Learning media is very important to pay attention to because from the teacher's point of view, the right learning media can help teachers deliver learning materials and facilitate the student learning process, while for students (students) the right learning method will make it easier for students to receive the material presented. The development of sophisticated technology today, encourages innovation in creating new learning media, one of which is visual-based media, one of which is using cartoons. Based on the results of several studies, it can be concluded that applying cartoon learning media can increase students' interest in participating in learning classes, assist students in receiving subject matter, and can reduce student anxiety.
\end{abstract}

Keywords: Learning Media, Cartoon, Education

\section{ABSTRAK}

Media pembelajaran merupakan bagian yang tak terpisahakan dari dunia pendidikan. Media pembelajaran menjadi sangat penting untuk diperhatikan karena dari sisi pengajar, media pembelajaran yang tepat dapat membantu pengajar dalam menyampaikan materi pembelajaran dan mempermudah proses belajar siswa, sedangkan bagi siswa (pelajar) metode pembelajaran yang tepat akan mempermudah pelajar menerima materi yang disampaikan. Perkembangan teknologi yang canggih saat ini, mendorong inovasi dalam menciptakan media pembelajaran yang baru, salah satunya dengan media berbasis visual salah satunya menggunakan kartun. Berdasarkan hasil beberapa penelitian dan beberapa wawancara baik guru di beberapa sekolah dan kampus maka dapat disimpulkan bahwa dengan menerapkan media pembelajaran kartun dapat meningkatkan ketertarikan siswa dalam mengikuti kelas pembelajaran, membantu siswa dalam menerima materi pelajaran, serta dapat menurunkan kecemasan pada siswa

Kata Kunci: Media Pembelajaran, Kartun, Pendidikan

Poppy Rulianai's email: poppyruliana30@gmail.com

Para penulis menyatakan tidak mempunyai konflik kepentingan dalam penelitian dan penerbitan publikasi ini.

Copyright (C) 2021 (Sujendro Hery Nurgroho).

Licensed under the Creative Commons Attribution-NonCommercial-ShareAlike 4.0 (CC BY-SA 4.0)Available at

http://caraka.web.id

Submitted: 21 Agustus 2021, Revised: 20 November 2021, Accepted: 31 December 2021 


\section{PENDAHULUAN}

Pendidikan merupakan hal terpenting yang harus diperhatikan. Persaingan tenaga kerja di dunia saat ini semakin tinggi, sehingga dunia pendidikan perlu melakukan berbagai inovasi dalam menghasilkan sumber daya manusia yang berkualitas. Pendidikan merupakan sarana agar siswa dapat mencapai tujuan dan meningkatkan kualitas hidupnya dan akan berdampak pada kemajuan suatu negara. Jika kualitas pendidikan rendah maka kemajuan suatu negara juga akan rendah (Wardaya, 2018).

Dunia pendidikan terus mengalami perkembangan yang signifikan dalam penyampaian informasi materi ajar kepada anak didik. Kondisi sekarang di saat pandemi sangat penting pemahaman bagaimana proses penyampaian sebuah informasi agar lebih mudah diterima oleh audiens. Dalam hal ini tentu perlu dukungan elemen sebagai penunjang yaitu visual kreatif, salah satunya adalah kartun. Dalam kehidupan keseharian, bisakah manusia terbebas dari dunia kartun? Di media cetak maupun media digital, kartun sudah menjadi bagian visual yang tidak terpisahkan. Penggambaran betapa pentingnya peran visual juga bisa diketahui dari sejarah penyampaian informasi tentang sebuah keadaan agar lebih mudah diterima oleh audiens.

Penemuan lukisan pada 44.000 tahun yang lalu menunjukkan lukisan seekor anoa sedang diburu oleh figur setengah manusia dan setengah hewan dengan tombak dan tali. Visual yang terlihat tentunya menjadi kemudahan bagi peneliti untuk menangkap makna yang terjadi pada saat itu. Visual mempunyai peran untuk memudahkan penyampaian sebuah informasi walau hanya berupa simbol, karena akan lebih mudah diterima penafsirannya, misalnya seperti penggambaran tokoh Mickey Mouse yang dipersonifikasikan dari seekor tikus. Kartun yang dibuat sebagai penunjang informasi agar mudah diterima audiens untuk selanjutnya memegang peran penting. Kartun yang ngetop di kalangan anak muda yaitu Si Juki, Dalang Pelo, Mice adalah gambaran maraknya komunikasi visual.

Sementara itu, media pembelajaran merupakan bagian yang tak terpisahkan dari dunia pendidikan. Media pembelajaran menjadi sangat penting untuk diperhatikan karena dari sisi pengajar, media pembelajaran yang tepat dapat membantu pengajar dalam menyampaikan materi pembelajaran dan mempermudah proses belajar siswa, sedangkan bagi siswa (pelajar) metode pembelajaran yang tepat akan mempermudah pelajar menerima materi yang disampaikan. Perkembangan teknologi yang canggih saat ini, mendorong inovasi dalam menciptakan media pembelajaran yang baru, salah satunya dengan media berbasis visual menggunakan kartun (Rusby et al., 2017).

Kartun adalah penggambaran dalam bentuk lukisan atau karikatur tentang orang, gagasan atau situasi yang didesain untuk memengaruhi opini masyarakat. Ada beberapa kualitas tertentu dari kartun-kartun yang efektif dalam pembelajaran. Kartun merupakan bentuk gambar yang umum dikenal masyarakat dan dapat ditemukan di berbagai media massa seperti surat kabar, majalah, buku teks, yang dengan mudah dan cepat digemari oleh semua kalangan baik anak-anak maupun orang dewasa. Kartun lebih dikenal mengandung unsur kebebasan sama seperti jenaka. Seperti halnya, dalam pembelajaran, kartun biasanya digunakan sebagai penguatan materi tertentu dalam materi yang diajarkan (Patonah et al., 2019).

Antara tahun 1970 - 1980, misalnya, buku pelajaran sekolah terbit dengan warna menyolok dan selalu ada visual kartun pada cover maupun pada isinya. Ilustrator yang pada saat itu sangat dikenal adalah Pak Suyadi yang pernah menjadi tokoh Pak Raden di Film Unyil. Mungkin kurang disadari oleh pendidik bahwa fungsi kartun di buku pelajaran sangat mempunyai peran yang tak kalah penting dibanding naskah.

Pada penelitina ini, peneliti melakukan wawancara dengan beberapa guru yang berkompeten 
di bidang pendidikan di daerah Bintaro, Kendal, Semarang, dan Bekasi yang beraktivitas pada mata pelajaran yang berbeda sehingga bisa membuka wawasan bahwa visual kartun menjadi lebih kuat perannya sebagai media komunikasi di sekolah. Penerapan metode pembelajaran dengan menggunakan kartun diperlukan karena dari beberapa hasil penelitian sebelumnya ada kendala yang ditemui saat proses pembelajaran yaitu: (1) pada umumnya kegiatan belajar di Indonesia masih konvensional; (2) pembelajaran terkesan membosankan; (3) siswa kurang antusias (Sukanta et al., 2017). Penelitian yang dilakukan oleh Patonah et.al (2019) menjelaskan bahwa siswa kerap kali merasa bosan pada saat proses kegiatan belajar.

\section{KERANGKA TEORI}

Media pembelajaran adalah segala sesuatu yang dapat digunakan untuk menyalurkan pesan (bahan pembelajaran) sehingga dapat merangsang perhatian, minat, pikiran, dan perasaan peserta didik dalam kegiatan belajar untuk mencapai tujuan pembelajaran (Budiman, 2016). Media pembelajaran meliputi alat yang secara fisik digunakan untuk menyampaikan isi materi pelajaran, misal buku, kaset, video, camera, film, foto, gambar dan lain-lain (Rusby et al., 2017). Dalam kegiatan belajar mengajar seorang guru harus pandai menggunakan media di dalam proses pembelajarannya, agar siswa tidak merasa jenuh dan merasakan pembelajaran yang menarik.

Kartun merupakan media penyampaian yang secara mudah menuangkan sebuah pesan dalam bentuk gambar sederhana yang bahkan tidak detil sehingga dikenali dan dimengerti dengan mudah oleh audiens. Fetty Wahyuni, seorang guru SD menyatakan, anak lebih senang melihat gambar visual kartun, karena menarik. Anak mudah memahami bagaimana bentuk sebuah binatang setelah seorang guru menyampaikannya dalam bentuk gambar. Kustiono, seorang guru Seni Budaya \& MultiMedia di SMKN Ungaran juga menyampaikan dengan visual kartun, anak tak mudah mengantuk dan lebih interaktif. Supporting visual kartun bisa diterapkan di berbagai mata pelajaran sekolah. Sebagai contoh, di masa pandemi, guru lebih mudah menjelaskan Covid-19 yang dikartunkan dibanding dengan tulisan.

Nur Riyani, seorang di SMAN 2 Bekasi juga menyampaikan dengan adanya gambar, maka penjelasan tentang materi ajar menjadi lebih mudah dipahami oleh siswa. Supporting gambar pada saat penyampaian materi ajar melalui Zoom lebih mudah diterima oleh siswa. Hal serupa disampaikan Winarni, guru di SMAN 8 Semarang yang menyampaikan bahwa penyampaian dengan supporting gambar, maka siswa menjadi lebih menangkap materi ajar dari seorang guru.

Supatmo, guru di Jurusan Seni Rupa, Fakultas Bahasa dan Seni UNNES mengatakan, daya serap pemahaman materi ajar akan lebih cepat dan mendalam bila didukung visual gambar. Taufiq Hidayat, dari SMPN 2 Bojong, Tegal, Jawa Tengah menyatakan dunia visual gambar kartun tanpa disadari sudah ada di sekolah, seperti di Perpusatakaan Sekolah, Tempat Parkir, Laboratorium sekolah yang lebih komunikatif divisualkan dengan gambar display dibanding hanya tulisan.

Dalam memilih alat pendidikan, ada beberapa hal yang perlu diperhatikan, yaitu; (1) tujuan yang ingin dicapai; (2) orang yang menggunakan alat; (3) untuk siapa alat itu digunakan; (4) efektivitas penggunaan alat dengan tidak melahirkan efek tambahan yang merugikan. Dari definisi media pembelajaran tersebut di atas, media pembelajaran sebenarnya melingkupi tiga jenis, yaitu (1) alat bantu mengajar, (2) alat peraga dalam mengajar, dan (3) sumber belajar. Di sisi lain media juga ada wujud konkretnya seperti kebendaan (papan tulis, buku, dan lain-lain) dan yang bersifat abstrak, seperti suara guru, muatan isi (Ramli, 20120).

Adapun manfaat khusus media pembelajaran menurut Budiman (2016) adalah: (1) menangkap suatu objek atau peristiwa penting yang langka, dapat diabadikan dengan foto, film atau direkam melalui video atau audio, kemudian peristiwa itu dapat disimpan dan digunakan 
manakala diperlukan; (2) memanipulasi keadaan, peristiwa atau objek tertentu. Melalui media pembelajaran guru dapat menyajikan bahan pelajaran yang bersifat abstrak menjadi konkret sehingga mudah dipahami dan dapat menghilangkan verbalisme. Misalnya untuk menyampaikan bahan pelajaran tentang sistem peredaran darah pada manusia, dapat disajikan melalui film dan sebagainya; (3) menambah gairah dan motivasi belajar peserta didik. Penggunaan media pembelajaran dapat menambah motivasi belajar peserta didik sehingga perhatian peserta didik terhadap materi pembelajaran dapat lebih meningkat. Sebagai contoh sebelum menjelaskan materi pelajaran tentang polusi, untuk dapat menarik perhatian peserta didik terhadap topik tersebut maka guru memutar film terlebih dahulu tentang banjir atau tentang kotoran limbah industri dan lain sebagainya.

Pembelajaran visual ialah pembelajaran melalui apa yang dilihat. Adapun ciri gaya belajar visual (Rusby et. Al., 2017) adalah: (1) teliti terhadap yang detail; (2) mengingat dengan mudah apa yang dilihat; (3) mempunyai masalah dengan instruksi lisan; (4) tidak mudah terganggu dengan suara; (5) pembaca cepat dan tekun; (6) lebih suka membaca dari pada dibacakan; (7) lebih suka metode domonstrasi dari pada ceramah; (8) bila menyampaikan gagasan sulit memilih kata; (8) rapih dan teratur; (9) penampilan sangat penting

\section{Media Kartun}

Kartun adalah penggambaran dalam bentuk lukisan atau karikatur tentang orang, gagasan atau situasi yang didisain untuk mempengaruhi opini masyarakat. Kartun adalah salah satu bentuk komunikasi grafis, yaitu suatu gambar interpretatif yang menggunakan simbol untuk menyampaikan sesuatu pesan secara cepat dan ringkas (Nurohimah et al., 2012).

Kartun merupakan suatu bentuk media komunikasi visual yang memiliki kekuatan untuk menyampaikan informasi secara populer dan mudah dimengerti. Kartun sebagai alat bantu mempunyai manfaat penting dalam proses pembelajaran, terutama dalam menjelaskan rangkaian isi bahan. Pembelajaran dengan kartun akan menciptakan belajar yang efektif karena dapat membawa siswa ke dalam suasana yang menyenangkan, selain itu pembelajaran dengan kartun dapat menciptakan suasana yang gembira (Nurohimah et al., 2012).

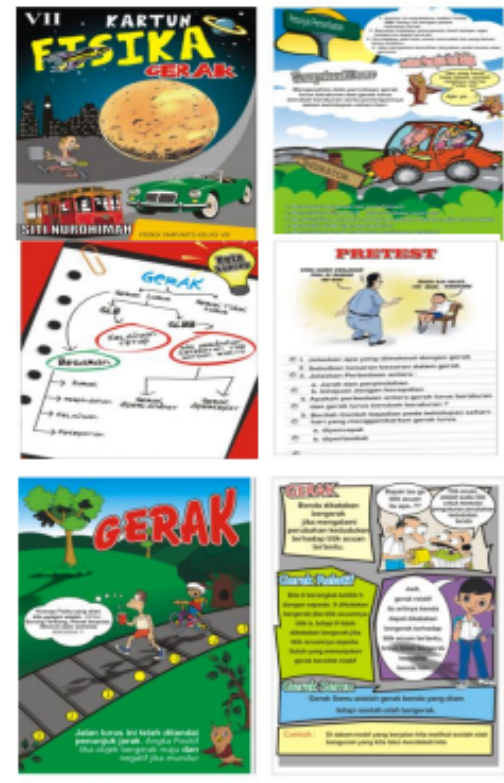

Gambar 1. Gambar Kartun Pada Pelajaran Fisika Sumber: Nurohiomah et al., 2012 
Karakter kartun yang baik menurut Ramli (2012) hanya mengandung satu gagasan saja. Ciri khas kartun memakai karikatur, sindiran yang dilebihlebihkan, perlambang dan humor pilihan. Dalam beberapa hal penggunaan kartun di bidang politik dan sosial dijadikan medium untuk menyerang pribadi para pejabat tinggi. Kekuatan kartun untuk dapat mempengaruhi pendapat umum, terletak pada kekompakkannya, penyederhanaan isunya, dan perhatian.

Menurut Ramli (2012) beberapa indikator yang menunjukkan sebuah kartun memiliki kualitas tinggi ialah: (1) pemakaiannya sesuai dengan tingkat pengalaman, artinya kartun yang digunakan hendaknya dimengerti oleh para siswa pada saat kartun tersebut digunakan; (2) kesederhanaan, hanya berisi hal yang penting-penting saja; (3) lambang yang jelas, kartun yang efektif adalah adanya kejelasan dari pengertian-pengertian simbolis.

Adapun media pembelajaran kartun menurut Ramli (2012) dapat digunakan dalam pembelajaran: (1) Untuk memotivasi. Sesuai dengan wataknya kartun yang efektif akan menarik perhatian serta menumbuhkan minat belajar siswa. Karena dapat meningkatkan daya tarik akan, sehingga dapat menjadi alat motivasi yang berguna di kelas; (2) Sebagai ilustrasi. Seorang guru melaporkan hasil efektif dari penggunaan kartun-kartun dalam menggambarkan konsep ilmiah pengajaran sain. Sebagian dipakai untuk mengemukakan beberapa pertanyaan tentang ada tidaknya situasi ilmiah yang dapat digambarkan dalam kartun. Sebagian lagi menggambarkan kesalahan-kesalahan dalam menafsirkan isi yang terkandung dalam kartun. Hal ini berarti dapat digunakan sebagai ilustrasi dalam kegiatan pembelajaran; (3) Untuk kegiatan siswa. Jenis lain dari kartun yang dipergunakan adalah kreasi kartun-kartun yang dibuat siswa sendiri. Para siswa membuat kartun untuk menumbuhkan minat dalam kampanye kebersihan, keselamatan mengemudi, keadilan, adab makan dan minum.

\section{METODOLOGI}

Penelitian ini menggunakan pendekatan kualitatif dengan rancangan penelitian deskriptif, menggambarkan fenomena yang sedang berkembang tanpa harus mencari hubungan atau pengaruh. Pengumpulan data dilakukan melalui tahap observasi, wawancara dengan beberapa pengajar yaitu guru dari Bintaro, Ungaran, Semarang, Kendal, dan Bekasi yang penggunakan materi visual kartun saat mengajar. Selanjutnya mengumpulkan dokumentasi, dan studi Pustaka. Aktivitas dalam analisis data kualitatif dilakukan secara interaktif dan berlangsung secara terus menerus sampai tuntas. Aktivitas dalam analisis data, yaitu data reduction, data display, dan conclusion drawing/verification (Sugiyono, 2012).

\section{HASIL PENELITIAN}

Pendidikan memegang peran penting dalam kehidupan seseorang karena pendidikan akan menentukan masa depan seseorang sehingga perlu sarana penyampaian komunikasi yang mudah diterima oleh siswa. Pada saat ini penyampaian materi oleh guru dari panduan di buku sebagai acuan yang hanya dibacakan, maka komunikasi akan berjalan kurang variatif. Kebosanan akan dialami oleh siswa bahkan sangat memungkinkan dialami oleh guru itu sendiri. Namun apabila guru mampu mendemokan pembahasan melalui aktivitas kartun agar lebih interaktif maka penerimaan bagi siswa akan lebih menyenangkan (Kirm, 2017).

Saat ini yang masih menjadi polemik adalah bahwa apakah seorang guru harus menjadi kartunis atau ilustrator, masuk ke dalam komunitas kreatif, ataukah harus memasuki kenbali perkuliahan yang berkaitan dengan seni rupa. Pembahasan dalam bidang kartun adalah mengupayakan seorang guru melakukan tindakan mempunyai aktivitas yang berbeda atau dengan kata lain seorang guru perlunya menyertakan aktivitas mengartun pada saat memberikan materi 
ajar. Hal ini penting karena guru melakukan tindakan yang terus berupaya agar dapat memecahkan persoalan untuk mata pelajaran yang menjadi kewajibannya.

Kirom (2017) menyatakan, kartun dibedakan berdasarkan kriterianya, yakni: (1) kartun editorial. Kartun editorial atau kartun politis biasanya ditujukan untuk menyatakan pandangan politik atau sosial dengan cara menyindir; (2) Gag cartoon, yaitu kartun yang dimaksudkan untuk melucu tanpa menyindir; (3) Kartun Karikatur, yaitu kartun dari karakter seseorang atau tokoh yang digambarkan dengan cara dilebihkan atau distorsi. Karikatur ini lebih ditujukan dengan menonjolkan karakter. Pada awal penciptaan karikatur digunakan sebagai sindiran pada negara atau politik; (4) Komik Setrip, yaitu adalah kartun dalam bentuk komik singkat.

Merujuk dari penjelasan di atas, maka pada poin pertama yaitu kartun editorial dan gag cartoon cenderung tidak bisa dilakukan oleh guru karena dalam visualisasinya memang membutuhkan pemikiran yang mendalam yang seringkali dilakukan oleh kartunis. Untuk pilihan ketiga yaitu komik setrip sangat memungkinkan dibuat oleh guru bahkan siswa sekalipun. Biasanya komik setrip ini bertema keseharian.

Apabila merujuk tentang kartun yaitu bahwa sebuah gambar yang mempresentasikan suatu peristiwa atau keadaan. Secara visual bahwa sebuah kartun mempunyai ciri: (1) Gambar atau coretan terlihat simpel atau ringkas, bahkan hanya dalam satu goresan saja; (2) Tidak menggunakan kata kata namun yang tersampaikan adalah kesan secara visual; (3) Mudah dikenali dan dipahami; (4) Agar sebuah informasi/ materi ajar agar terlihat lebih unik.

Kartun bisa dikembangkan sebagai media penunjang dalam menyampaikan media ajar dengan adanya penjelasan (Sujendro, 2020) yakni: (1) Adanya kesesuaian dengan tujuan belajar mengajar. Kartun sebagai penunjang media belajar untuk materi pelajaran apapun lebih mudah dikolaborasikan dengan naskah agar siswa menjadi lebih nyaman menerima materi. Hal ini berbeda apabila materi ajar banyak menampilkan teks yang berpotensi kejenuhan siswa; (2) Adanya kesesuaian dengan karakteristik peserta didik. Dunia pendidikan mulai dari TK hingga perguruan tinggi selalu membutuhkan keunikan dalam penyampaian materi ajar. Salah satu keunikan tersebut bisa dilakukan dengan aktivitas kartun secara visual; (3) Perlunya kesesuaian dengan gaya mengajar. Dengan mempelajari kartun, sebetulnya yang menyesuaikan adalah kartunnya bukan lagi pendidik. Hal ini juga menjadi kemudahan bahwa seorang pendidik tidak perlu menjadi ekspert sebagai kartunis.

Beberapa penelitian menjelaskan pada dasarnya pembelajaran dengan menggunakan media kartun dapat meningkatkan kemampuan siswa. Penelitian Yunitasari (2014) pada siswa kelas III SD menjelaskan bahwa kemampuan menulis karangan narasi dengan menggunakan media kartun lebih tinggi dari pada kemampuan menulis karangan narasi peserta didik yang tidak menggunakan media kartun. Penelitian Maharani et al., (2018) menjelaskan bagaimana pengggunaan media pembelajaran kartun untuk mata pelajaran matematika pada siswa kelas VII SMP.

Penelitian ini dilakukan pada dua kelompok yakni kelompok besar dan kelompok kecil. Pada kelompok kecil dan kelompok besar, belajar matematika dengan menggunakan metode kartun dinilai sangat menarik bagi siswa di dua kelompok tersebut. Penelitian ini juga menganalisis penurunan kecemasan siswa dalam pembelajaran matematika. Penggunaan media pembelajaran menggunakan kartun dapat menurunkan tingkat kecemasan siswa. Pada kategori kecemasan tinggi menurun dari $41 \%$ menjadi $0 \%$, kategori kecemasan sedang mengalami penurunan dari $35 \%$ menjadi $24 \%$, kategori kecemasan rendah berubah dari $24 \%$ menjadi $76 \%$.

Hasil pengamatan yang dilakukan oleh Putra (2021) pada kelas XI SMA Muhammadiyah di Kota Makassar, menunjukkan bahwa pembelajaran fisika yang dilakukan secara konvensional dengan penjelasan yang ditulis di papan tulis membuat para siswa terlihat bosan dan kurang 
termotivasi dalam menerima pelajaran. Hal ini mengakibatkan minat belajar menurun. Akibatnya hasil belajar yang diperoleh siswa kurang memuaskan. Sedangkan fisika merupakan pelajaran yang banyak mengandung konsep-konsep abstrak sehingga memerlukan perangkat pembelajaran yang dapat membuat konsep-konsep abstrak menjadi lebih konkrit arahnya sehingga materi lebih mudah dipahami. Hasil penelitiannya menunjukkan, penggunaan media kartun dalam pembelajaran fisika di kelas mampu menciptakan suasana yang menyenangkan dan mengurangi kejenuhan serta dapat meningkatkan keaktifan belajar para siswa.

Kepraktisan media ajar terdiri dari dua aspek, yaitu kemudahan dan kemanfaatan. Aspek kemudahan dikategorikan baik. Hal ini membuktikan bahwa media pembelajaran ini mudah digunakan, dapat dioperasikan di berbagai aplikasi pemutar, serta mudah dalam perawatannya. Aspek manfaat dikategorikan baik. Hal ini menunjukkan bahwa media dapat memfasilitasi peserta didik untuk menguasai materi, membantu mereka secara mandiri, membuat peserta didik mengingat materi lebih baik, membantu siswa untuk fokus, membuat siswa tertarik pada materi, dan membuat siswa belajar lebih cepat dari biasanya sesuai dengan kebutuhan (Putra, 2021).

Penerapan metode pembelajaran dengan kartun perlu melalui beberapa tahap antara lain, (1) tahap pendefinisian (define), (2) tahap perencanaan (design) dan (3) pengembangan (develop) dan tahap penyebaran (disseminate). Define, mendefinisikan dan menetapkan syarat-syarat pengembangan media pembelajaran berbasis kartun merupakan tujuan yang akan dicapai pada tahap penelitian ini. Pada tahap perencanaan, dilakukan untuk merancang media pembelajaran berbasis kartun. Develop, tahap ini dilakukan untuk menghasilkan media pembelajaran berbasis kartun. Tahap terakhir ialah tahap penyebaran. Tahap diseminasi dilakukan untuk mempromosikan produk pengembangan agar bisa diterima pengguna, baik individu, suatu kelompok atau sistem (Maharaniet al., 2018).

\section{KESIMPULAN}

Menerapkan media pembelajaran kartun dapat meningkatkan ketertarikan siswa dalam mengikuti kelas pembelajaran, membantu siswa dalam menerima materi pelajaran, serta dapat menurunkan kecemasan pada siswa. Peran kartun sebagai media komunikasi visual media ajar di dunia Pendidikan menjadi pelengkap informasi sebuah materi ajar agar dalam penyampaian kepada peserta didik menjadi lebih menyenangkan. Kartun bisa pula dikatakan sebagai penyampai pesan karena termasuk bagian dari materi ajar. Tak bisa dipungkiri bahwa informasi selalu didukung adanya aktivitas visual. Sebuah peristiwa atau pembahasan apabila disampaikan secara tertulis, naskah yang ditampilkan baik pada saat offline maupun online akan kurang optimal.

Kemanfaatan kartun yang mempunyai peran tidak kecil di dunia komunikasi Pendidikan. Support personil akan lebih lengkap membantu seorang pendidik agar menguasai kartun sesuai dengan tingkatan dan keinginan pendidik. Informasi di berbagai situs tetap diperlukan agar pengetahuan tentang kartun menjadi lebih optimal. Pembelajaran melalui kartun akan bagus apabila dikembangkan di berbagai institusi pendidikan sejak dari TK hingga perguruan tinggi. Hal ini didasari bahwa ilmu komunikasi tidak bisa lepas dari dunia visual dan visual yang paling menarik adalah kartun. Pengembangan kartun di dunia pendidikan sangatlah menantang untuk dijalankan secara optimal dengan tujuan memberi kemudahan pada saat penyampaian materi ajar kepada peserta didik. Prosentase sinerginya antara mentoring kartunis selalu berimbang.

DAFTAR PUSTAKA

Budiman, H. (2016). Penggunaan Media Visual Dalam Proses Pembelajaran. Jurnal Pendidikan Islam, 7. 5-24. 
Hery, S. (2020). Gak Ngarikatur Gak Cuan. Elex Media Komputindo

Maharani, M., Supriadi, N., \& Widyastuti, R. (2018). Media Pembelajaran Matematika Berbasis Kartun untuk Menurunkan Siswa Pendahuluan pada Era Kemajuan Ilmu Pengetahuan di Abad Ini, Pendidikan Terus Menjadi Topik Menarik Untuk Diperbincangkan Oleh Banyak Pihak, Tanpa Pendidikan, Manusia Yang Hi. Desimal: Jurnal Matematika, 1(1), 101-106

Nurohimah, M., Supriadi, N.,\& Widyastuti, R. (2018). Pemanfaatan Kartun Fisika Sebagai Media Pembelajaran untuk Meningkatkan Belajar pada Siswa Kelas VII MTS. N Purworejo. Radiasi, 1(1), 45-48.

Patonah, D., Wijaya, W. M., \& Rosalin, E. (2019). Efektivitas Penggunaan Media Gambar Kartun Pada PEmbelajaran Untuk Meningkatkan Berhitung Peserta Didik Sekolah dasar. Jurnal Penelitian Pendidikan, 19(1), 37-45, Https://Doi.Org/10.17509/Jpp.V19il.17130.

Putra, D. P. (2021). Pengembangan Media Pembelajaran Fisika Menggunakan Kartun 3D. Jurnal Literasi Digital, 1(2), 88-93.

Ramli, M. (2012). Media Teknologi Pemnbelajaran. IAIN Antasari Press.

Rusby, Z., Hayati, N., \& Cahyadi, I. (2017). Upaya Guru Mengembangkan Media Visual DalamProses Pembelajaran Fiqih Di MAN Luok Bangkian Kabupaten Kampar. Al-Hikmah: Jurnal Agama dan Ilmua Pengetahuan, 14(1), 18-37, Https://Doi.Org/10.25299/Al-Hikmah:Jaip.Vol14(1).1170

Sukanta, W., Ahmad, S., \& Aisyah, S. (2017). Pengaruh Media Pembelajaran Film Kartun Terhadap Hasil Pelestariannya Di Kelas VII SMP Negeri 1 Belitang liii KAbupaten Oku Timur Tahun Pelajaran 2016/ 2017. Jurnal Swarnabhumi, 2(1), 23-29

Wardaya, M. (2018). Visual Media as Assisting Instrument to Improve Students Listening Ability. Visual Communication Design Journal, 3(1), 1-12.

Yunitasari, (2014). Pengaruh Penggunaan Media Kartun Terhadap Kemempuan Menulis Karangan Narasi Peserta Didik lii SD. In Artikel Penelitian Universitas Tanjungpura. Tanjungpura Pontianak. 